\title{
繊維強化ポリマーの界面剥離自己修復
}

\author{
真 田 和 昭
}

\section{Self-Healing of Interfacial Debonding in Fiber Reinforced Polymers}

Kazuaki SANADA (Toyama Prefectural University, 5180 Kurokawa, Imizu-shi, Toyama 939-0398, Japan) sanada@putoyama.ac.jp

The interface between the fiber and matrix has a major influence on the mechanical properties of fiber reinforced polymers (FRPs). Damages at the interface such as interfacial debonding can cause a reduction in strength and stiffness of FRPs. As a result, the structural capability of the FRP is reduced, and premature failure can result if the damage is not detected and repaired. However, microscopic damage such as interfacial debonding is extremely difficult to detect and repair by conventional methods. The current research suggests that repair of microscopic damage can be accomplished by incorporating repair components into the FRP. This novel concept is that of self-healing. The idea of a self-healing material has led to significant interest in the current literature. Many techniques have focused on the ability to heal microscopic damage in FRPs. In this paper, we present an overview of various self-healing concepts for FRPs, and recent progress and advances that have been made on self-healing of interfacial debonding in FRPs.

Key Words : Composite Material, Microcapsule, Interfacial Debonding, Self-Healing

\section{1. は じめ に}

近年，緘維強化ポリマー（Fiber Reinforced Polymer, FRP）の用途は, 航空宇宙, 自動車, 船船等幅広い分野に 拡大しており, FRPの安全性, 信頼性の確保に対する社 会的要求が非常に高まっている。一方，FRPの利用拡大 に伴い，その廃裹物は年々増加する傾向にあるが，再利用， 再資源化されているのはごく少量であり，大部分は焼却お よび埋め立て処分され，環境への負荷が大きくなっている のが現状である．FRPの廃棄物処理による環境問題を解 決するためには，優れた強度を長期間維持できる FRPを 開発して廃㪰物を低減することが，最善の方策である。

FRPの強度低下を引き起こす損傷としては，マトリッ クス（ポリマー）の微視破壊，繊維とマトリックス間の界 面剥離等があるが，これらは微小で材料内部に発生するた め, 検出して外部から修復することは非常に困難である. また，界面剥離はFRPが不均質材料であるために発生を 防ぐことは困難であり, 使用の初期段階から容易に発生し, 突発的なマク口破壊の原因となる。 そこで，生命体のよう に，FRP自体に損傷を自己修復させる機能を持たせよう とする研究が国内外で活発に行われている。ここでは，国 内外の自己修復性を有する FRPの開発動向を述べるとと もに, 使用時の FRPの強度を著しく低下させる要因であ
る瀻維とマトリックス間の界面剥離を自己修復する FRP 開発を目指した理論的実験的研究について紹介する.

\section{2. 国内外の自己修復性を有するFRPの開発動向}

FRPのマトリックスは, 熱可塑性樹脂と熱硬化性樹脂 に大きく分類できるが，構造用部材等としての用途には， エポキシ樹脂等の熱硬化性樹脂をマトリックスとした FRPが多く用いられている。熱硬化性樹脂をマトリック スに用いたFRPの自己修復は，主として修復剤を用いて き裂面を再接着することで実現しようと試みられている. 以下に，これまで報告された熱硬化性樹脂をマトリックス に用いたFRPの自己修復に関する研究例を分類して示す。

\section{1 中空繊維に液体の修復剤を閉じ込める方法}

$\mathrm{Dry}^{1)}$ は，図1に示すように，修復剤を入れた中空繊維 を用いて熱硬化性樹脂に自己修復性を付与する手法を提案

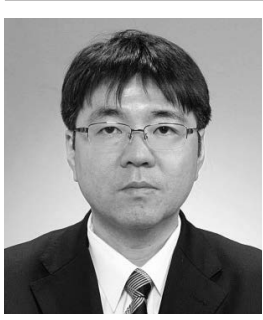

真田 和昭; 富山県立大学工学部機械システ 厶工学科（テ 939-0398富山県射水市黒河 5180） 准教授. 博士 (工学). 平成 11 年, 東北大学大 学院工学研究科材料加工学専攻博士課程修了. 同年，日立製作所日立研究所入社，平成 15 年 富山県立大学工学部講師, 平成 21 年富山県立 大学工学部准教授，現在に至る。専門は，複 合材料工学. 


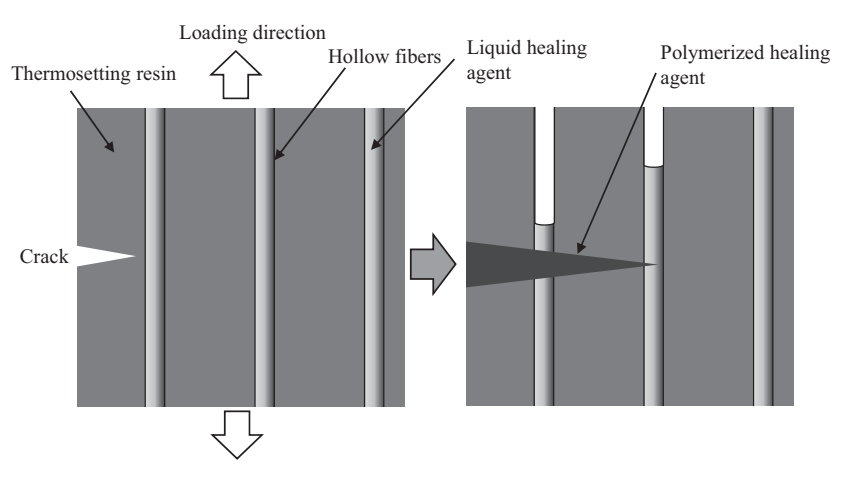

Figure 1 Self-healing concept using hollow fibers

している．これは，熱硬化性樹脂とともに破壊した中空緎 維から修復剤㧍よび硬化剂（あるいは修復剤のみ）が流出 し，き裂に浸透し硬化して，き裂面を接着する手法である. Motuku ら ${ }^{2)}$ は，実際のFRPへの中空瀻維による自己修 復性付与を目指して, 通常の瀻維と中空瀻維を組み合わせ て作製したガラス緎維/ビニルエステル樹脂積層板および ガラス纎維/エポキシ樹脂積層板を対象に, 衝撃試験を行 い，衝撃特性に及ぼす中空繊維の直径（1.15～1.6mm） と 素材（ガラス，銅，アルミニウム）の影響について検討し ている。しかし, 積層板の衝撃特性に対する自己修復効果

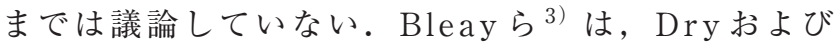
Motukuらが検討した中空瀻維は, 通常の瀻維に比べて, 外径が大きいため，FRPに適用した場合に破壊の起点と なる可能性を指摘し, 外径 $15 \mu \mathrm{m}$, 内径 $5 \mu \mathrm{m}$ のガラス中 空纎維とエポキシ樹脂を用いて作製した積層板を対象に, 衝撃試験を行い，衝撃後圧縮強度に対する自己修復効果に ついて検討している. Pang と Bond ${ }^{4,5)}$ は，中空纎維に閉 じ达める修復剤の容量増大による自己修復効果向上を目指 し，外径 $60 \mu \mathrm{m}$ のガラス中空纎維を用いて作製したガラ ス繊維/エポキシ樹脂積層板を対象に，衝撃負荷後の 4 点 曲げ試験を行い，曲げ強度の回復効果を検討している。 ま た，紫外線蛍光染料を用いて，損傷領域への修復剤の流出 状況を観察している. Traskら ${ }^{6.7)}$ は，外径 $60 \mu \mathrm{m}$ のガラ ス中空纎維を用いて作製したガラス緎維/エポキシ樹脂積 層板および炭素繊維/エポキシ樹脂積層板を対象に，衝撃 負荷後の 4 点曲げ試験を行い，曲げ強度に対する自己修復 効果について検討している．以上のように，中空䗡維を用 いたFRPへの自己修復性付与の手法に関しては，大量の 修復剂を細い中空繊維で効率良く閉じ込め，FRPの強度 低下を最小限にする技術の確立を目指して, 研究開発が進 められている。

\section{2 マイクロカプセルに液体の修復剤を閉じ込める方法}

White ら) $^{8)}$ は，図 2 に示すように，修復剤を内包したマ イクロカプセルを用いて熱硬化性樹脂に自己修復性を付与 する手法を提案している。これは，熱硬化性樹脂とともに 破壊したマイクロカプセルから放出された修復剤が，き裂

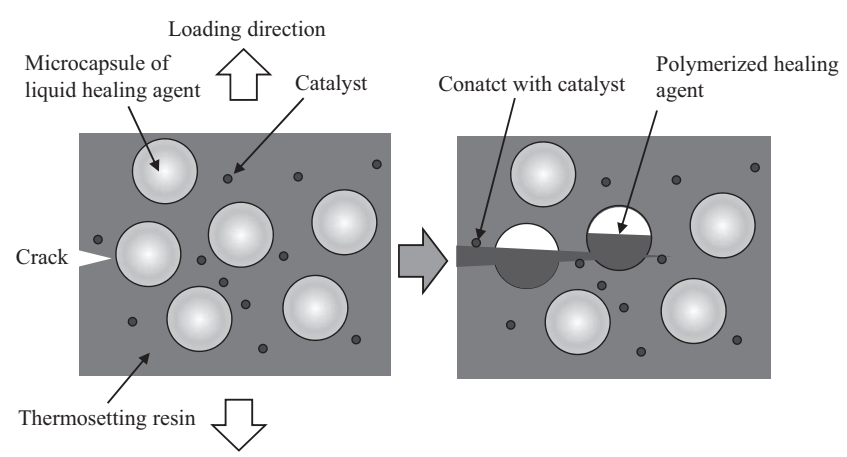

Figure 2 Self-healing concept using embedded microcapsules

に浸透し，熱硬化性樹脂中に分散した硬化触媒と接触する ことにより硬化して，き裂面を接着する手法である。 Kessler ら ${ }^{9,10)}$ は, 硬化触媒としてGrubbs触媒を分散した エポキシ樹脂を含浸したプリプレグを用いたガラス繊維/ エポキシ樹脂積層板を対象に, DCB (double cantilever beam）試験片を用いたモードI層間破壊勒性試験を行い， 層間剥離部に修復剤としてジシクロペンタジエン (DCPD) を注入することで，層間剥離が修復することを検証してい る。また，DCPDを内包したマイクロカプセルと Grubbs 触媒を分散したエポキシ樹脂を含浸したプリプレグを用い て自己修復性を付与したガラス瀻維/エポキシ樹脂積層板 を対象に, WTDCB (width-tapered double cantilever beam）試験片を用いたモードI層間破壊勒性試験を行い， 層間破壊靱性に対する自己修復効果について検討してい

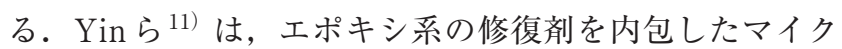
ロカプセルと潜在性の硬化触媒を分散したエポキシ樹脂を 含浸したプリプレグを用いて自己修復性を付与したガラス 瀻維/エポキシ樹脂積層板を対象に，DCB 試験片を用いた モードI層間破壊勒性試験を行い，層間破壊靱性に対する 自己修復効果について議論している. 以上のように，マイ クロカプセルを用いた FRPへの自己修復性付与の手法に 関しては，層間等の樹脂がリッチな部分にマイクロカプセ ルが疑集してしまうため，層間剥離に対してのみ高い修復 効果が確認されているのが現状である。今後, FRP内に マイクロカプセルを均一分散する技術の開発が重要であ り，層間剥離以外の損傷に対する自己修復性付与が課題と なっている。

\section{3 マトリックスに固体の修復剤を直接分散させる方法}

固体の修復剤を用いて自己修復性を付与する手法は，損 傷部を加熱して固体の修復剤を溶融させ，き裂に浸透させ た後，再び修復剤を固化させて，き裂面を接着することで 実現している，Zakoと Takano ${ }^{12)}$ は，マトリックス中に 室温で粉末状のエポキシ樹脂の粒子（粒径50 $\mu \mathrm{m}$ ）を分散 させたガラス繊維/エポキシ樹脂積層板を対象に， 3 点曲 げ試験および疲労試験を行い，剛性㧍よび強度に対する自 己修復効果を検討している. Hayesら ${ }^{13)}$ は，マトリック 


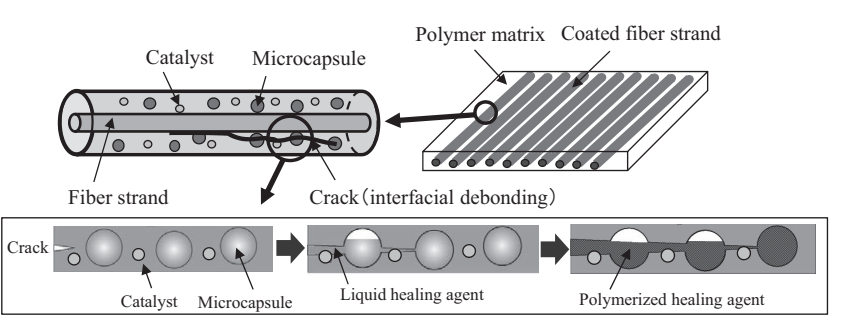

Figure 3 Self-healing system of interfacial debonding in FRPs

ス中に熱可塑性樹脂を分散させたガラス瀻維/エポキシ樹 脂積層板を対象に，衝撃試験を行い，初期と修復後の損傷 領域の大きさで自己修復効果を評価している．以上のよう に，固体の修復椷による FRPへの自己修復性付与の手法 に関しては，様々な修復剤が提案され，自己修復効果が確 認されているが，実際にFRPを機器に適用した場合を想 定した損傷部の検出手法と局所的に固体の修復剂を溶融さ せるための加熱手法の開発が重要となっている.

\section{3. 界面剥離自己修復性を有する FRPの開発}

\section{1 界面剥離自己修復性付与の手法}

図3に筆者らが提案した界面剥離自己修復性付与の手法 を示す ${ }^{14)}$ 。これは，Whiteらが提案した修復郕入りマイク ロカプセルを用いた熱硬化性樹脂に対する自己修復性付与 の手法を応用したもので，繊維ストランド表面に修復郕入 りのマイクロカプセルと硬化触媒を混合したポリマーをコ ーティングすることで，界面剥離を積極的に修復する機能 を付与している。

\section{2 繊維と垂直方向の引張試験による強度回復効果の 検証と微視構造最適化}

DCPDを内包したマイクロカプセルとGrubbs触媒を混 合したエポキシ樹脂をコーティング・半硬化させた繊維ス トランドを作製した。この緎維ストランドを用いて一方向 FRP（自己修復FRP）を作製し，纎維と垂直方向 $\left(90^{\circ}\right.$ 方向）の引張試験を行って，界面剥離に対する修復効果を 検討した ${ }^{14)}$ 。図 4 は初期および修復後の自己修復FRPの 応力ーひずみ曲線を示したもので，初期の引張試験で試験

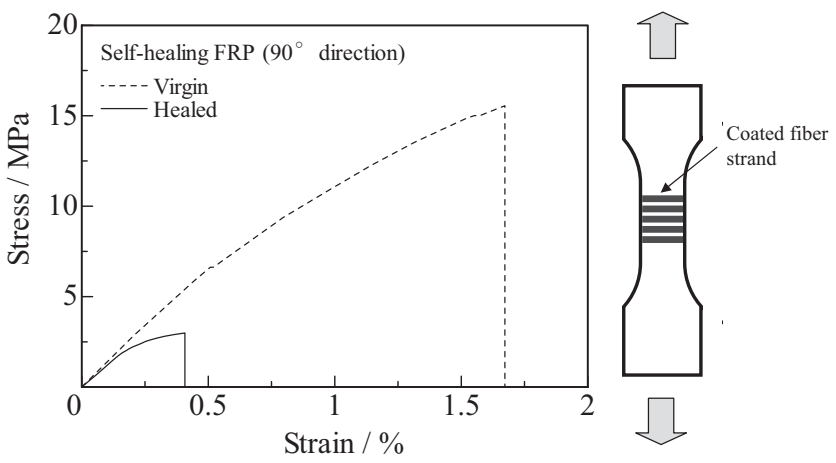

Figure 4 Stress-strain curves for Virgin and healed self-healing FRP specimens
片を完全に破断させた後, 破断面を合わせて万力で固定し, 室温で 24 時間，さらに $80{ }^{\circ} \mathrm{C}$ で 24 時間自己修復させて再度 試験を行った結果である。引張強度に対する修復率 $\eta$ は次 式より求めた。

$$
\eta=\frac{\sigma_{C}^{\text {healed }}}{\sigma_{C}^{\text {virgin }}}
$$

ここに， $\sigma_{C}^{\text {virgin }}$ は初期の試験片の引張強度， $\sigma_{C}^{\text {healed }}$ は修復 後の試験片の引張強度である。瀻維と垂直方向に負荷した 場合，自己修復FRPは繊維・マトリックス間の界面剥離 によって最終破壞した。また，図4の場合，自己修復FRP の繊維と垂直方向の引張強度に対する修復率は $19 \%$ とな った.

自己修復FRP の微視構造と強度回復効果の関係を明ら かにするために，マイクロカプセル粒径，纎維ストランド のフィラメント数等を変化させた纎維と垂直方向 $\left(90^{\circ}\right.$ 方向）の引張試験を行った ${ }^{15)}$. 図 5 に自己修復FRPの初 期および修復後の引張強度・修復率とマイクロカプセル粒 径の関係を示す。初期の引張強度はマイクロカプセル粒径 の減少に伴い低下した。これは，初期負荷時にマイクロカ プセルがエポキシ樹脂と剥離することにより形成される欠 陥に起因すると考えられ，小さい粒径のマイクロカプセル ほど容易に剥離していると予想される。これに対し，修復 後の引張強度は，非常にばらつきが大きく，マイクロカプ セル粒径の影響を強く受けなかった。

引張負荷を受けるコーティング層内のマイクロカプセル とエポキシ樹脂との剥離挙動を解明するため, ユニットセ ルモデルを用いた有限要素解析を行った ${ }^{15)}$ 。マイクロカ プセルとエポキシ樹脂の剥離は，モードIの剥離のみ生じ ると仮定した cohesive zoneモデルにより考虑した。眓6 はマイクロカプセルとエポキシ樹脂の剥離挙動に及ぼすマ イクロカプセル粒径の影響を示したもので，縦軸はマイク ロカプセルの接着面積の割合，横軸はユニットセルに負荷 した変位をユニットセルの寸法で無次元化した量を示して

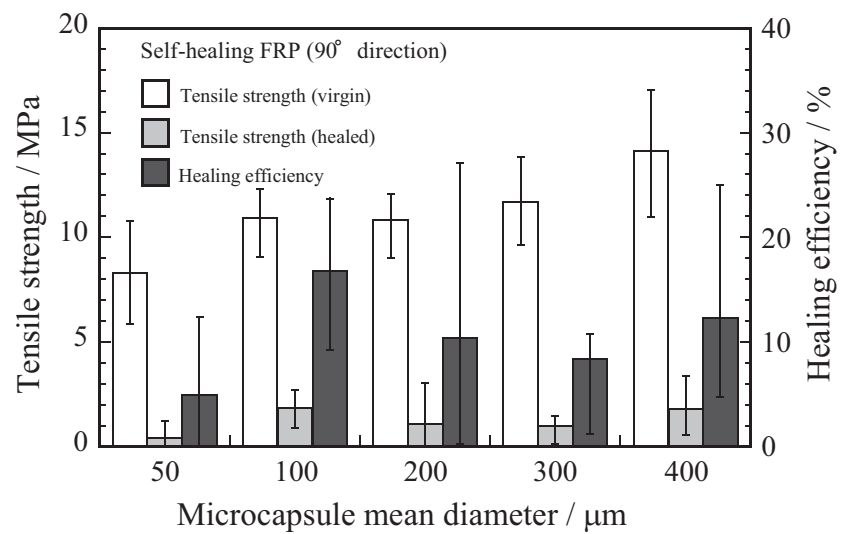

Figure 5 Tensile strengths for Virgin and healed self-healing FRP specimens, and healing efficiency vs. microcapsule mean diameter 


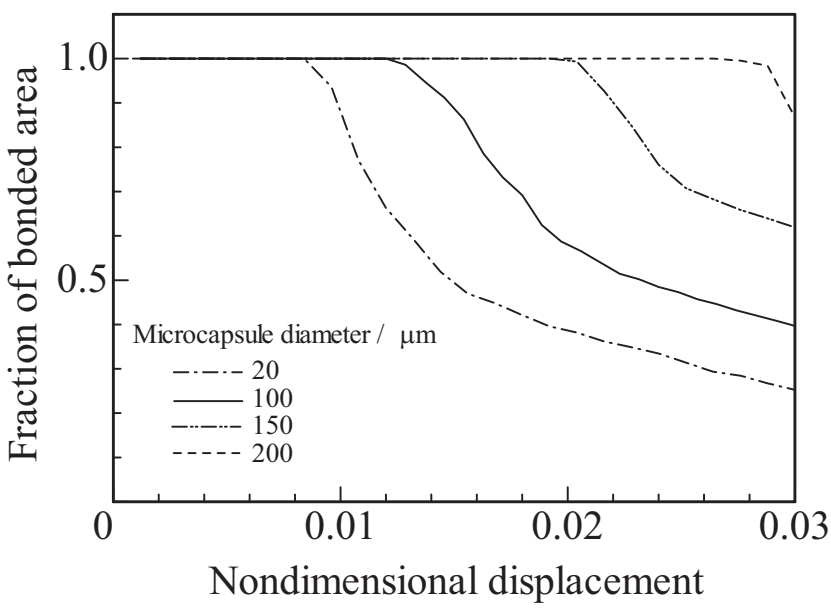

Figure 6 Effect of microcapsule diameter on debonding behavior

Loading direction

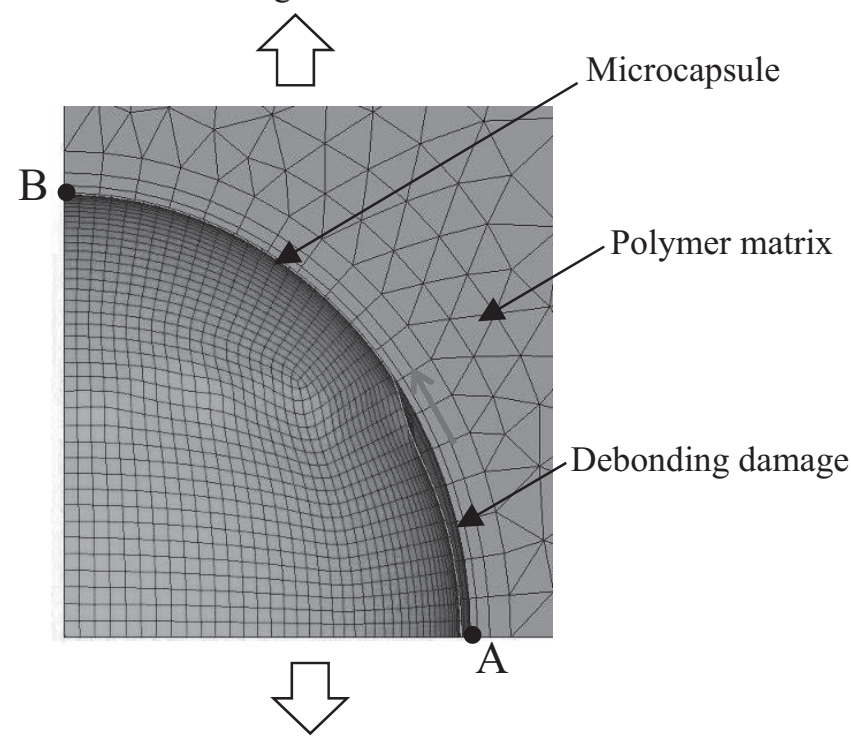

Figure 7 Predicted debonding damage growth pattern in the unit cell model

いる．マイクロカプセル粒径の減少に伴い小さな変位でマ イクロカプセルとエポキシ樹脂との剥離が発生しており, 粒径の小さなマイクロカプセルほど容易に剥離する傾向を 示した。また，この傾向は，図5に示すマイクロカプセル 粒径の減少に伴い初期の引張強度が低下する原因がマイク ロカプセルとエポキシ樹脂との剥離に関係していることを 裏付けた。図 7 に有限要素解析で得られたマイクロカプセ ルとエポキシ樹脂との剥離の進展パターンを示す。マイク ロカプセルとエポキシ樹脂との剥離は, A 点から発生し, 負荷した変位の増大に伴い $\mathrm{B}$ 点に向かって進展した。エポ キシ樹脂中を進展するき裂は，A点付近に到達すると考え られるため, 剥離の初期段階でもマイクロカプセルの破壊 が生じにくくなると予想される.

\section{3 繊維方向の引張試験による強度回復効果の検証と 損傷進展解析}

マイクロカプセルを用いて界面剥離自己修復性を付与し
たFRPの縁き裂材試験片（SENT 試験片）を対象に，繊 維方向 $\left(0^{\circ}\right.$ 方向 $)$ 引張試験と紫外線蛍光剤による損傷領 域観察を行い, 界面剥離自己修復による強度回復効果を評 価した ${ }^{16)}$ 。まず，DCPDを内包したマイクロカプセルと Grubbs触媒を混合したエポキシ樹脂をコーティングした 繊維ストランドを用いて，自己修復FRPを作製し，引張 試験を行った。図 8 は初期および修復後の自己修復FRPの 荷重一変位曲線を示したもので，2回大きく荷重降下した 時点で初期試験を中断し，除荷後，室温で 10 日間自己修 復させて再度試験を行った結果である。最大荷重に対する 修復率は次式より求めた。

$$
\eta=\frac{P_{C}^{\text {healed }}-P^{\text {residual }}}{P_{C}^{\text {virgin }}-P^{\text {residual }}}
$$

ここに, $P_{C}^{\text {virgin }}$ は初期の試験片の最大荷重, $P_{C}^{\text {healed }}$ は修復 後の試験片の最大荷重, $P^{\text {residual }}$ は初期試験を中断した時 の荷重である．修復後の荷重－変位曲線に修復効果が認め られ，修復後の最大荷重は，初期の結果とほぼ同じ值を示 した。また，図8の場合，自己修復FRPの最大荷重に対す る修復率は $98 \%$ となった。次に，自己修復効果を検証す るために，マイクロカプセルだけを混合したエポキシ樹脂
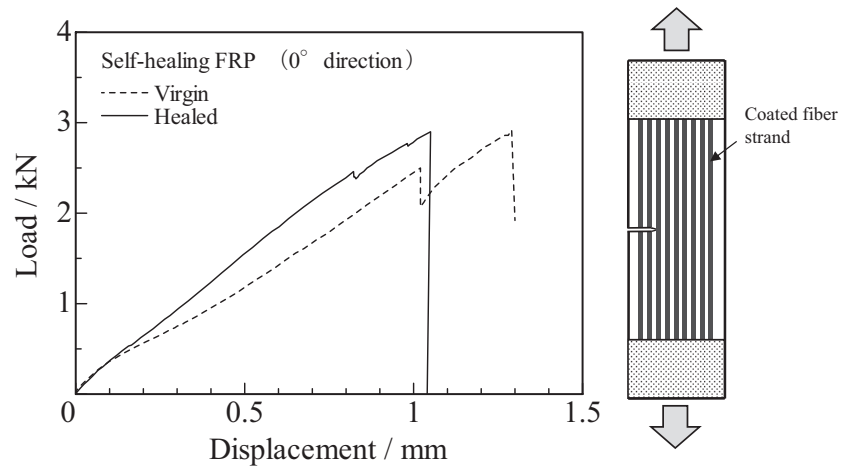

Figure 8 Load-displacement curves for Virgin and healed selfhealing FRP specimens

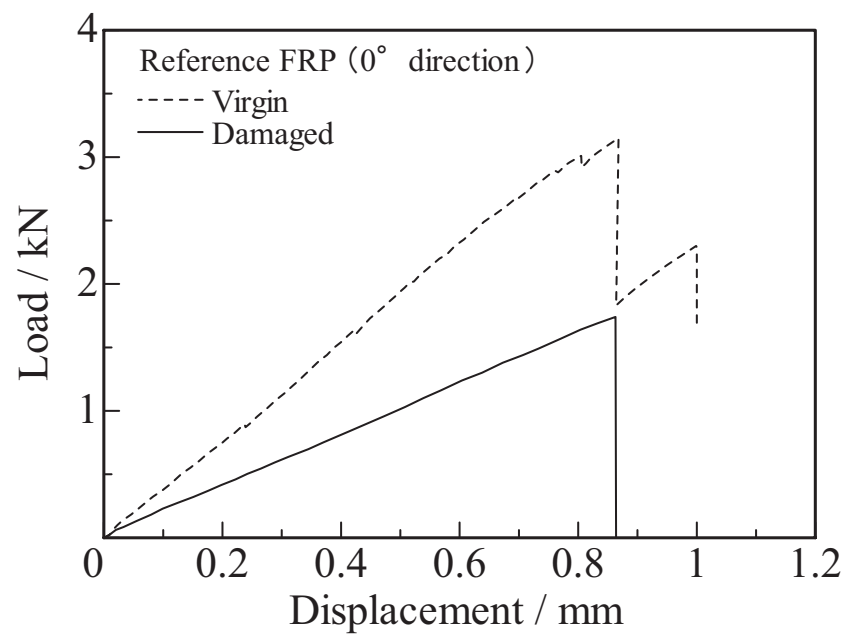

Figure 9 Load-displacement curves for Virgin and damaged reference FRP specimens 


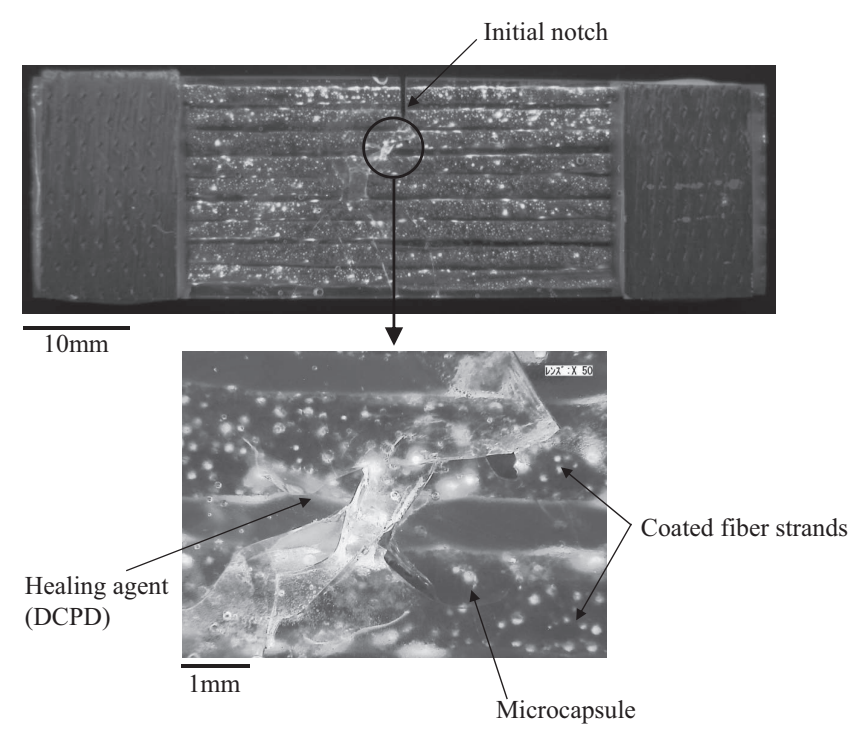

Figure 10 Optical micrograph of damages observed in a self-healing FRP containing the microcapsules with a UV fluorescent dye

をコーティングした繊維ストランドを用いてリファレンス FRPを作製し，引張試験を行った.リファレンス FRPは， Grubbs触媒を未混合とすることで，マイクロカプセルか ら放出された修復剤が硬化しないようにしたもので，自己 修復効果を示さないFRPである。図 9 は初期および損傷後 のリファレンス FRPの荷重－変位曲線を示したもので, 2 回大きく荷重降下した時点で初期試験を中断し, 除荷後, ただちに再度試験を行った結果である。再試験で得られた リファレンス FRPの最大荷重は，初期試験を中断した時 点の荷重とほぼ一致し, 図 8 に示す最大荷重の回復は界面 剥離自己修復による効果であることが明らかとなった。し かし, 試験片によって損傷進展挙動が大きく異なり, 修復 率が大きくばらつく結果となった。図 10 に紫外線蛍光剤 と DCPDを内包したマイクロカプセルを用いた自己修復 FRPの紫外線照射による損傷領域観察結果を示す。破壊 したマイクロカプセルから流出したDCPDがマトリック スの微視き裂に浸透している様子が観察でき，界面剥離 （繊維ストランド表面のコーティング層内での破壊）が生 じていることを確認した.

自己修復 FRPの縁き裂材引張試験に関する損傷進展解 析を行い，損傷進展挙動に及ぼす試験片厚さ等の影響を検 討した ${ }^{17)}$ 。解析は，対称性を考慮し, SENT試験片の4分 の 1 の領域について行った。図 11 に試験片厚さ $2 \mathrm{~mm}$ の SENT 試験片の損傷進展解析結果を示す。試験片厚さ 2 $\mathrm{mm}$ の場合，マトリックスの微視破壊は，予き裂先端から 発生し, 繊維ストランドに到達後, 顕著なコーティング層 の微視破壊を伴い繊維ストランドに沿って進展した。この 場合，コーティング層内のマイクロカプセルが顕著に破壊 し，修復剤が放出されるため，自己修復効果を示す可能性 が高い. しかし, 試験片厚さ $3 \mathrm{~mm}$ の場合, マトリックス

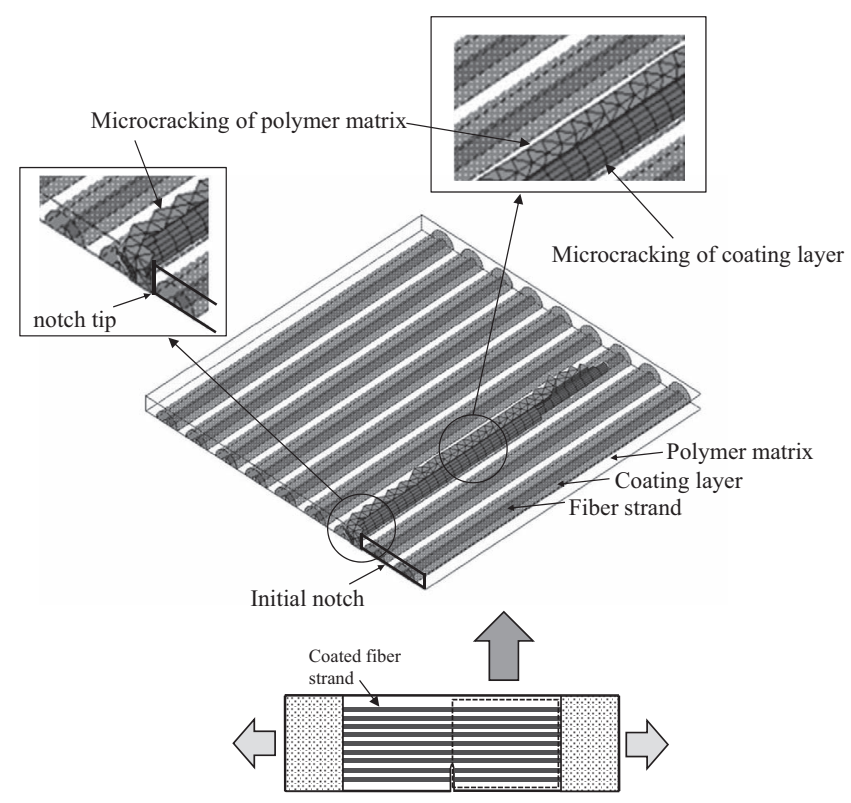

Figure 11 Predicted damage growth pattern in the SENT specimen with thickness of $2 \mathrm{~mm}$ at the applied displacement value of $0.5 \mathrm{~mm}$

の微視破壊は繊維ストランドに沿って進展しなかった。こ の場合，マイクロカプセルがほとんど破壊しないため，自 己修復効果を示さない。実験においても，試験片厚さ $2 \mathrm{~mm}$ の場合, 損傷が繊維ストランドに沿って進展し, 自 己修復効果を示した試験片が，試験片厚さ $3 \mathrm{~mm}$ の場合に 比べて多かった。

\section{4. お わ りに}

国内外の自己修復性を有するFRPの開発動向を述べる とともに，界面剥離を自己修復する FRP 開発を目指した 理論的実験的研究について紹介した。FRPは, 不均質な 内部構造を有し, 破壊挙動が複雑なため, 高分子材料単体 の場合に比べて，高い効果を発現する自己修復性を付与す ることは困難である。しかし，自由に材料設計できるとい う複合材料の利点を生かして, 多くの自己修復機能付与の 手法が提案され, 実用化に向けた開発が進んでいる. 今後, FRPの利用分野はより一層拡大し，信頼性・耐久性に対 する要求は厳しくなり，環境負荷への配慮も必須となるた め, FRPへの自己修復性付与は必要不可欠になると予想 される。

\section{Reference}

1 ) Dry, C.: Compos. Struct., 35, 263 (1996)

2 ) Motuku, M.; Vaidya, U. K.; Janowski, G. M.: Smart Mater. Struct., 8, 623 (1999)

3 ) Bleay, S. M.; Loader, C. B.; Hawyes, V. J.; Humberstone, L.; Curtis, P. T.: Composites:Part A, 32, 1767 (2001)

4 ) Pang, J. W. C.; Bond, I. P.: Compos. Sci. Technol., 65, 1791 (2005)

5 ) Pang, J. W. C.; Bond, I. P.: Composites:Part A, 36, 183 (2005)

6 ) Trask, R. S.; Williams, G. J.; Bond, I. P.: J. R. Soc. Interface, 4, 363 (2007) 
7 ) Williams, G. J.; Trask, R. S.; Bond, I. P.: Composites: Part A, 38, 1525 (2007)

8 ) White, S. R.; Sottos, N. R.; Geubelle, P. H.; Moore, J. S.; Kessler, M. R.; Sriram, S. R.; Brown, E. N.; Viswanathan, S.: Nature, 409 $794(2001)$

9 ) Kessler, M. R.; White, S. R.: Composites:Part A, 32, 683 (2001)

10) Kessler, M. R.; Sottos, N. R.; White, S. R.: Composites:Part A, 34, 743 (2003)

11) Yin, T.; Zhou, L.; Rong, M. Z.; Zhang, M. Q.: Smart Mater. Struct., 17, 015019 (2008)

12) Zako, M.; Takano, N.: J. Intell. Mater. Sys. Struct., 10, 836 (1999)

13) Hayes, S. A.; Zhang, W.; Branthwaite, M.; Jones, F. R.: J. R. Soc. Interface, 4, 381 (2007)

14) Sanada, K.; Yasuda, I.; Shindo, Y.: Plast. Rubber Compos., 35, 67
(2006)

15) Sanada, K.; Itaya, N.; Shindo, Y.: Open Mech. Eng. J., 2, 97 (2008)

16) Sanada, K.; Mizuno, Y.; Shindo, Y.: Nippon Kikaigakkai 2009nendo Nenjitaikai Kouenronbunshu, 8, 9 (2009)

17) Sanada, K.; Mizuno, Y.; Shindo, Y.: Nippon Kikaigakkai M\&M2011 Zairyou Rikigaku Conference CD-ROM Ronbunshu (2011)

\section{日本語表記参考文献}

16）真田和昭, 水野雄太, 進藤裕英 : 日本機械学会 2009 年度年次大 会講演論文集，8, 9 (2009)

17）真田和昭, 水野雄太, 進藤裕英：日本機械学会 M\&M2011材料 カ学カンファレンス CD-ROM 論文集 (2011)

\section{本会発行出版物ご案内}

\section{ゴ山用 語 辞 典 B 6 版 400 頁 (1997.10発行)

$\begin{array}{lrc}\text { 定 価 } & 4,725 \text { 円(税込) } \\ \text { 会員価格 } & 4,252 \text { 円(税込) } \\ \text { 送 料 } & 450 \text { 円 }\end{array}$

(ゴム産業に係わる技術用語，製品用語を幅広く収録したものです．収録用語約 4,500 語. )

* お申込の場合は，必要事項(送付先住所，勤務先，氏名，電話番号など)をご記入のうえ， FAXして下さい. 